\title{
BAHASA AL-QURAN TENTANG SEKSUALITAS MENURUT TAFSIR AL-MISHBAH DAN RELEVANSI DENGAN PENDIDIKAN DAN GENDER
}

\author{
Risman Bustamam ${ }^{1}$ \\ risman.bustamam@iainbatusangkar.ac.id
}

\begin{abstract}
Abstrak: Tulisan ini bertujuan untuk menjelaskan data-data linguistic dan interpretasi tematik tentang model bahasa Al-Quran-sebagai kitab sucidalam membicarakan perihal seksualitas pada diri manusia, yang mana pembahasan tema ini secara social selama ini dianggap sebagai 'hal keji dan karenanya juga tabu'. Selain itu, tulisan ini juga bertujuan untuk meninjau model bahasa Al-Quran dimaksud dari perspektif pendidikan seksual dan gender. Untuk itu, kajian ini menggunakan pendekatan metode tafsir linguistic- semantic dan tematik, dengan sumber data utamanya adalah ayat-ayat Al-Quran dan tafsir al-Mishbah karya Quraish Shihab, dengan kajian perspektif pendidikan khususnya pendidikan seksual dan perspektif gender. Hasil penelitian ini menunjukkan bahwa model bahasa Al-Quran dalam membicarakan masalah seksualitas manusia adalah bahasa yang halus, simbolik, dan etis, dan lebih menekankan pada aspek normatif pendidikan seksual, selain aspek hukum yang menjadi isi utama ayat-ayatnya, serta sangat menunjukkan pentingnya pemahaman gender dalam relasi seksualitas antarmanusia. Artinya pendekatan pilihan bahasa Al-Quran yang multitafsir bisa dikembangkan sebagai bahasa edukatif-normatif dalam membicarakan issu-issu gender dan seksualitas.
\end{abstract}

Kata Kunci: manusia, seksualitas, pendidikan, gender, bahasa.

\section{PENDAHULUAN}

Al-Quran sebagai kitab suci yang diturunkan dari Allah swt. untuk manusia, semua isi dan kandungannya tentu sesuai dengan keseluruhan potensi manusia, guna membimbing dan mewujudkan kemaslahatan mereka. Karena itu, Islam disebut sebagai agama fithrah (potensi dan eksistensi asasi), sesuai dengan makna yang dikandung QS.al-Rum/30: 30. QS.al-Rum/30: 30 ini menjelaskan bahwa

\footnotetext{
${ }^{1}$ Penulis merupakan Lektor Kepala bidang Ilmu Al-Quran dan Tafsir, Dosen tetap pada Jurusan Ilmu Al-Quran dan Tafsir dan PPS IAIN Batusangkar, lulusan Islamic Studies Konsentrasi Tafsir Hadis pada UIN Syarif Hidayatullah Jakarta.
} 
Allah telah menciptakan manusia di atas fithrah. Artinya, Al-Quran sebagai sumber utaman Islam mengandung ajaran yang sejalan dengan fitrah manusia. Dari itu, AlQuran tentu mengungkap dan menjelaskan banyak hal tentang manusia dan potensinya. Salah satu potensi dan kebutuhan fitri manusia yang diungkap dan dijelaskan Al-Quran adalah tentang seksualitas manusia. Terdapat sejumlah term dalam Al-Quran yang mengungkap atau menjelaskan perihal seksualitas manusia.

Seks adalah kelamin dalam pengertian biologis, yaitu alat kelamin pria dan wanita, sedangkan seksualitas mengandung pengertian segala sesuatu yang berhubungan dengan seks itu. Maka, dalam term seksualitas termasuk di dalamnya nilai, orientasi, dan perilaku seksual, tidak semata-mata seks sebagai kelamin manusia secara biologis (Pangkahila, 2001, hal. 1). Secara fitriah, manusia adalah makhluk seksual. Manusia memiliki seks (kelamin secara biologis) dan memiliki potensi seks alias seksualitas. Justru itu, Islam melalui Al-Quran sangat memperhatikan masalah seks dan seksualitas ini. Besarnya perhatian Islam terhadap masalah seks dan seksualitas manusia ini antara lain ditandai dengan banyaknya ayat Al-Quran yang memakai term-term yang terkait dengan seks, dan lalu berisi penjelasan atau pengaturan masalah seksualitas.

Sebagai contoh dapat dilihat pada redaksi Al-Quran ketika menyebut istilah hubungan seks suami istri berikut:

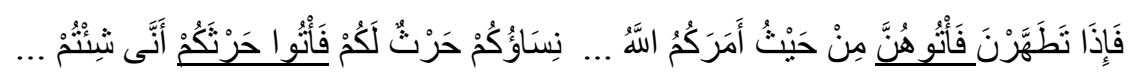

Kedua ayat tersebut di atas menunjukkan betapa Al-Quran menggunakan bahasa atau ungkapan yang sangat halus dan sopan dalam menjelaskan tentang hubungan seks uami istri, yakni menggunakan kata فَاَْتُو yang artinya mendatangi, bukan menggunakan kata الجِمَاعُ dan yang bermakna bersetubuh atau bersenggama itu sendiri (Abdul Mujied, 1994, Cet.2, hal. 141).

Ada pandangan yang menyatakan, antara lain menurut Riyanti, ketika AlQuran membicarakan masalah seksualitas yang sangat sensitif ini selalu diungkapkan dengan bahasa yang penuh kesopanan. Al-Quran mengungkap tentang hubungan seksual dengan berbagai term tidak langsung alias majazi; almubâsyarah (menggauli), al-mulâmasah (menyentuh), al-ifdhâ', dan atau dengan 
term al-ityân (mendatangi). Penggunaan terma-terma ini oleh Al-Quran menunjukkan suatu bahasa isyarat atau sindiran yang mengundang perenungan dan tidak menimbulkan rasa malu, serta terjauh dari kesan vulgar, porno atau cabul. Bagi Riyanti, tujuan Al-Quran menggunakan bahasa seperti itu adalah untuk mengarahkan perhatian manusia pada aspek kelembutan dan adab dalam melakukan hubungan seksual. Al-Quran dalam hal ini telah mengajarkan tentang kesopanan dalam membicarakan masalah seksualitas yakni dengan menggunakan ungkapan kinayah yang halus. Ini merupakan bukti kuat bahwa Al-Quran bersifat realistis, berusaha menyeimbangkan antara aspek perasaan subjektif dan aspek hasrat seksual alamiah pada diri manusia (Blog.riyanti.web.com., diakses; Rabu, 22 Sept 2010, jam 14.56). Pertanyaannya; benarkah demikian adanya? Perlu penelitian untuk mengujinya.

Di sisi lain, realitas banyaknya ayat Al-Quran tentang seksualitas tidak sepenuhnya dipahami dan ditempatkan oleh sebagian umat secara baik dan tepat. Misalnya, pada tahun 2006 muncul pernyataan kontroversial sekaligus menggelitik dari salah seorang tokoh Islam Indonesia, Abdurrahman Wahid, yang menyatakan bahwa Al-Quran adalah kitab suci yang paling porno. Pendapat ini menyulut kritikan dan penolakan dari banyak pihak. Penolakan itu antara lain tercermin pada buku Hartoni Ahmad Jaiz yang berjudul Al-Quran Dihina Gus Dur (Ahmad Jaiz, 2006, hal. 4, buku dalam versi ebook dalam Swara Muslim Cyber Book).

Menurut penulis, menyatakan pembicaraan Al-Quran tentang seksualitas sebagai hal yang 'porno atau tidak porno', selama ini masih merupakan persoalan kesan dan persepsi pribadi seseorang terhadap teks belaka. Persepsi demikian tentu wajar dipandang dari sisi subjektifitas, namun secara ilmiah pernyataan demikian perlu dipertanggungjawabkan. Maka menurut penulis, agaknya sikap dan pendapat yang perlu dibangun adalah melakukan penelitian ilmiah tentang 'ayat-ayat seksualitas' di dalam Al-Quran. Penelitian ilmiah akan memberi ruang terbaik dalam membicarakan dan meneliti 'ayat-ayat seksualitas di dalam Al-Quran' karena ia merupakan bagian nyata dari isi Al-Quran. Di sisi lain, harus pula diakui dan ditegaskan bahwa Al-Quran, meskipun ada di dalamnya 'ayat-ayat seksualitas' 
bukanlah kitab seks/seksualitas. Al-Quran adalah kitab suci dan hidayah, karena itu tujuan Al-Quran membicarakan masalah seksualitas itu tidak untuk tujuan sensualitas dan pornigrafi, melainkan tidak terlepas dari fungsinya sebagai kitab hidayah.

\section{MASALAH DAN METODOLOGI}

Sehubungan dengan itu, mengkaji masalah seksualitas melalui analisis ayatayat Al-Quran adalah hal penting di saat media modern terkadang lebih cenderung permissive dan eksploitatif terhadap seks dan seksualitas. Media yang mengeksploitasi seks bisa berbahaya bagi generasi muda Islam. Secara objektif dan normatif, sesungguhnya pembahasan tentang seks dan seksualitas adalah bagian dari upaya normal manusia untuk memenuhi kebutuhan asasinya. Mencari pengetahuan tentang seks merupakan upaya seorang manusia untuk mengenali dirinya dan kebutuhan fitrinya itu. Karena itu, bisa dikatakan, pendidikan dan pengetahuan tentang seks dan seksualitas sesungguhnya sama pentingnya dengan kebutuhan manusia akan pendidikan dan pengetahuan di bidang-bidang lainnya; ekonomi, teknologi, agama, dan sebagainya. Salah satunya caranya yang aman sekaligus religius adalah dengan menggunakan studi terhadap ayat-ayat Al-Quran yang membicarakan seks/seksualitas manusia.

Kajian tulisan ini merupakan hasil penelitian penulis tahun 2011 di LPPM IAIN IB Padang, dengan tujuan mengkaji tentang bagaimana sesungguhnya bahasa Al-Quran mendeskripsikan seksualitas manusia. Kajian ini ingin membuktikan apakah deskripsi Al-Quran tentang seksualitas itu memang jauh dari unsur porno atau cabul, melainkan penuh nilai etik dan edukasi. Juga apakah deskripsi Al-Quran tentang seks/seksualitas tersebut mengindikasikan pembedaan gender atau perbedaan gender?

Kajian ini fokus pada masalah; bagaimana bahasa Al-Quran -Kitab suci Umat Islam- dalam mendeskripsikan masalah seksualitas manusia, yang mana masalah seksual itu secara social masih ada yang me-nabu-kannya untuk dibahas dan adanya pihak yang menolak mengaitkannya dengan isi Al-Quran? Maka batasan penelitian ini adalah: Bagaimana Al-Quran mendeskripsikan kelamin 
manusia sebagai organ biologis? Bagaimana Al-Quran mendeskripsikan kelamin manusia sebagai identitas gender? Bagaimana Al-Quran mendeskripsikan tentang kondisi/fungsi kelamin manusia sebagai alat reproduksi?nBagaimana Al-Quran mendeskripsikan tentang aktifitas dan hubungan seksual?

Dalam mengkaji masalah ini, penulis melakukan penelitian kepustakaan (Library Reseacrh). Penelitian ini adalah dalam rangka untuk melacak dan mengumpulkan data-data kepustakaan untuk menganalisis terma-terma di dalam ayat Al-Quran tentang seks dan atau seksualitas manusia, serta mendeskripsikannya secara tematis dan sistematis, sehingga menghasilkan sebuah kerangka konseptual ilmiah tentang seks/seksualitas di dalam Al-Quran serta nilai-nilai yang dikandungnya.

Kajian ini adalah penelitian tafsir dari perspektif pendidikan seks dan perspektf gender. Sebagai kajian tafsir, sumber primer dari kajian penulis ini adalah ayat ayat Al-Quran yang terkait tema/terma seks/seksualitas dan tafsir Muhammad Quraish Shihab, Tafsir al-Misbah. Sebagai pembandingnya digunakan Tafsir Abu al-Fida ibn Katsir (701H/1301M - 774H/1372M), Tafsir al-Quran al-Azhim. Dalam kajian ini penulis sedikit menggunakan pendekatan tafsir tematik, tafsir filologis (linguistic-semantik), dan seksologi. Dalam hal kajiam linguistic-semantik Arab penulis menggunakan buku al-Mufradat karya al-Ashfahani.

\section{HASIL PENELITIAN:}

\section{Terma Al-Quran tentang Kelamin sebagai Organ Biologis}

Term yang digunakan Al-Quran dalam menyebut kelamin adalah kemaluan: al-Farj (الفرج). Secara etimologis kata الفرج berasal dari kata فرج jamaknya adalah فرج Kata cerarti celah antara dua hal, atau tempat yang tersembunyi. Kata ini di dalam Al-Quran dipakai untuk makna organ vital kelamin perempuan dan juga organ vital kelamin laki-laki (al-Ashfahânî, 1972, hal. 388). Sebab, baik pada kelamin laki-laki maupun perempuan memang ada 'celah' baik dalam fungsinya sebagai saluran pembuangan maupun saluran seksualitas. Dengan demikian, term faraj tidak mengindikasikan lebih pada gender perempuan, melaikan juga laki-laki. 
Hal ini nanti relevan juga dengan kewajiban menutup farj, yang tidak hanya diwajibkan kepada perempuan meliankan juga kepada laki-laki (QS.al-Nur/24: 30$31)$.

Kata al-Farj berasal dari akar kata $f-r-j($ (ف-ر). Akar kata ini digunakan Al-Quran sebanyak 9 kali; kata kerja furijat 1 kali (al-Mursalat/77: 9); kata furuj 1 kali (Qaf/50: 6); kata farjaha 2 kali, (al-Anbiya'/21: 91, al-Tahrim/66: 12) dan furujahum 4 kali (al-Mukminun/23: 5, al-Nur/24: 30, al-Ahzab/33: 35, alMa`arij/70: 29), dan kata furujahunna 1 kali; al-Nur/24: 31 (Abdul Bâqî, 1987, Tanpa Cet.ke., hal. 514).

Dari data yang diperoleh di atas, ternyata di dalam Al-Quran, penggunaan kata al-farj adalah untuk penyebutan organ vital/kelamin manusia, yakni sebanyak 4 kali yang digunakan untuk menyebut organ kemaluan manusia secara umum, yakni furujahum (QS.al-Mukminun/23: 5, al-Nur/24: 30, al-Ahzab/33: 35, alMa`arij/70: 29), dan penggunaan yang terkait dengan kemaluan perempuan dengan term farjaha 2 kali (QS.al-Anbiya'/21: 91, al-Tahrim/66: 12) dan furujahunna 1 kali; QS.al-Nur/24: 31, serta furujahum 4 kali (`Abdul Bâqî, hal. 514).

Di dalam Al-Quran dan Terjemahnya Depag RI, kata farj diterjemahkan dengan 'kehormatan' (Tim Al-Quran dan Terjemahnya, hal. 506). Kata farj ini digunakan Al-Quran selalu dikaitkan dengan 'penjagaan atau pemeliharaan organ kemaluan atau kehormatan' dengan term أحصنت فرجها (al-Anbiya'/21: 91 dan alTahrim/66: 12), keduanya digunakan dalam kaitan Maryam yang disebut sebagai perempuan suci, tak ternoda lelaki. Ketika digunakan dalam bentuk term furujahum atau furujahunna (al-Mukminun/23: 5, al-Nur/24: 30, al-Ahzab/33: 35, alMa`arij/70: 29), semuanya juga terkait dengan term hafazhah (pemeliharaan, penjagaan) terhadap kehormatan kelamin laki-laki dan perempuan.

Dengan demikian, dapat dinyatakan bahwa term farj di dalam Al-Quran tidak untuk menyebut secara eksplisit tentang organ biologis kelamin laki-laki dan atau perempuan, melainkan lebih pada aspek kelamin sebagai kehormatan uang harus dijaga. Ini artinya faraj tidak lah ungkapan yang vulgar tentang kelamin biologis manusia. Meskipun secara bahasa term farj menunjukkan suatu 'organ 
yang memiliki celah atau lobang dan tempat yang tersembunyi', namun ternyata pembicaraan Al-Quran tentang farj lebih sebagai kemaluan dan kehormatan yang harus dijaga dan dipelihara kaum laki-laki dan perempuan.

Kelamin juga disebut Al-Quran sebagai aurat dengan term al-Sau'ah seakar dengan kata su', sayyi'ah, dan sayyi', dari akar kata $s-y-a(w-(w)$. Kata $s u$ ' berarti segala sesuatu yang menutupi atau menggelapkan keadaan kehidupan manusia di dunia dan akhirat, dan keadaan tidak baik yang meliputi kejiwaan dan jasmani, dan kondisi kekurangan harta, kehormatan. Kata sayyi'ah berarti perbuatan jelek, lawan dari hasanah, sedangkan kata sau'ah merupakan istilah untuk menyebut kemaluan manusia (al-Ashfahânî, hal. 252-253). Maka secara etimologis, sau'ah mengarah pada kelamin manusia yakni organ tubuh manusia yang rentan terhadap hal jelek atau perilaku tercela dan akan memalukan bilamana dilihat oleh orang lain. Maka term ini kemudian diartikan ulama sebagai kemaluan atau aurat.

Akar kata sau' atau su' dengan segala derivasinya sangat banyak digunakan Al-Quran yakni 167 kali. Tetapi Al-Quran menggunakan term ini dalam bentuk term sau'ah dalam kaitan dengan tubuh manusia hanya 7 kali, yakni; term sau'ah 2 kali yang dalam Al-Quran dan Terjemahnya dimaknai 'mayat atau bangkai' (QS.al-Maidah/5: 31), dan 5 kali untuk makna aurat yakni sau'atakum 1 kali (QS.alA`raf/7: 26), dan sau’atuhuma 4 kali (QS.al-A`raf/7: 20, 22, 27, 121) ('Abdul Bâqî, hal. 370). Ini artinya Al-Quran dengan term sau'ah ingin menyatakan bahwa kelamin manusia adalah aurat yang jelek bila diperlihatkan, atau orangnya akan dipandang jelek atau merasa malu manakala kemaluannya dilihat orang lain. Ini motivasi Al-Quran juga agar manusia tidak membuka aurat.

Selanjutnya Al-Quran menyebut kelamin sebagai identitas biologis, dengan term al-Dzakar wal al-Untsa (الذكر و الأنثى). Term dzakar asal katanya adalah ذكر. Term dzikir berasal dari akar kata $d z-k-r$, yang darinya antara lain lahir kata mengingat, mempelajari, menyebut sesuatu yang penting dan berkesan alias menonjol. Kata al-dzakar seakar dengan kata al-dzikr, al-dzikra, dan sebagainya. Akar kata $d z-k$-r digunakan Al-Quran sebanyak 184 kali. Menurut ibn Fâris salah 
satu makna asalnya adalah dzikr al-syai' (mengingat sesuatu), lawan dari nasiya (lupa) (ibn Fâris, 1994, Cet., I, hal. 388). Dalam makna 'mengingat' term $d z i k r$ bisa diwujudkan dengan $d z i k r$ bi al-qalb (dengan hati/pikiran) atau melalui perkataan (dzikr bi al-lisân).' Tidak diketahui dengan jelas kaitan antara term al-dizkr dan aldzakr. Setidaknya, mungkin terkait dengan sifat fisiknya yang 'mencolok' dan karakter lelaki yang lebih rasional ketimbang perempuan. Term dzakar dalam kaitan kelamin manusia; jantan atau laki-laki, lawan dari perempuan/betina (alAshfahânî, hal.181-182). Dengan demikian secara etimologis dzakar adalah jenis kelamin laki-laki yang mencerminkan karakter logis, kuat, dan mudah belajar.

Sebaliknya, kata al-untsa terdiri dari huruf a-n-ts-ya الأنثى) dari kata أنثى). Menurut ibn Faris dan Ibrahim Anis dijelaskan bahwa makna asal kata $a$ - $n$-ts ini adalah lan, lam yatasyaddid (lemah, lembut, tidak keras, halus). Tempat disebut anits adalah tempat yang mudah dan menarik, dan pedang yang anits adalah yang tajam. Kata al-untsa digunakan untuk menyebut lawan zakar (lelaki, jantan) (ibn Fâris, Mu’jam al-Maqâŷ̂s, hal. 93). Dengan demikian, secara etimologis untsa adalah jenis kelamin perempuan yang menunjukkan cirri; selalu menarik bagi lelaki, halus dan lembut. Kata al-untsa digunakan sebanyak 18 kali, al-untsayaini sebanyak 6 kali, dan inatsa sebanyak 6 kali (‘Abdul Bâqî, hal. 93).

Menurut Nasaruddin Umar, term al-dzakar lebih berkonotasi kepada persoalan biologis (seks), oleh karena itu al-dzakar sebagai lawan dari al-untsa juga digunakan untuk spesies lain selain manusia yakni binatang dan tanaman. Padanan kata ini adalah male dan female dalam bahasa Inggris. Penggunaan term dzakar dalam Al-Quran tersebut mengacu kepada konteks makna bahasa Arab juga. Artinya, kata ini lebih banyak digunakan untuk menyatakan laki-laki dilihat dari faktor biologis atau seks, misalnya pada QS.Alu Imran/3: 36 dan al-Syura/42: 50 tentang istri Imran yang melahirkan anak perempuan Maryam. Penggunaan kata dzakar dan untsa terkait dengan kelamin binatang misalnya pada QS.al-An`am/6: 143 (Nasaruddin Umar, 2001, Cet.II, hal. 164-165). Dengan demikian term dzakar dan untsa lebih berkaitan dengan hal-hal yang bersifat biologis atau jenis kelamin yang menunjukkan ciri spesiesnya; jantan dan betina, yang secara eksplisit bukan 
organ kelamin itu sendiri, namun secara implisit bisa dipahami sebagai organ kelamin. Dari perspektif gender, dapat dikatakan bahwa term al-dzakar dan aluntsa selain menunjukkan karakter seksual laki-laki dan perempuan, juga mengindikasikan perbedaan gender, yakni tentang karakter 'alamiah' laki-laki dan perempuan, bahwa dzakar adalah jenis kelamin laki-laki yang mencerminkan karakter mereka yang lebih logis, kuat, dan mudah belajar, sedangkan untsa adalah jenis kelamin perempuan yang menunjukkan cirri mereka yang selalu menarik bagi lelaki, halus, berperasaan, dan lembut..

Dari kajian tentang term-term Al-Quran mengenai seks atau organ dan jenis kelamin manusia secara biologis, dapat disimpulkan bahwa Al-Quran mengungkap organ dan jenis kelamin manusia secara objektif dan realistik, dengan pelbagai dimensinya. Term farj digunakan Al-Quran untuk mengisyarat bahwa kelamin manusia adalah organ yang berlubang/berongga dan berada ditempat yang tertutup, yang memalukan bila dilihat orang sehingga ia disebut dengan kemaluan dan kehormatan. Kelamin disebut Al-Quran dengan sau ah yakni organ vital yang menunjukkan suatu aurat dan memiliki potensi aib atau sumber perbuatan keji zina yang pasti membawa celaka. Al-Quran menyebut kelamin dengan dzakar dan untsa karena lebih menekankan jenis kelamin jantan dan betina, dengan sifat kejantanan pada lelaki dan kelembutan pada perempuan. Semua penggunaan semua term kelamin tersebut tidak menonjolkan vulgaritas atau porno, juga tidak secara tegas untuk membedakan gender mereka, melainkan pada eksistensi dan sifat alamiah, serta pentingnya penjagaan dan pemeliharaan kelamin dari perbuatan tercela dan keji.

\section{Terma Al-Quran tentang Kelamin sebagai Identitas Gender}

Kelamin sebagai identitas gender disebut Al-Quran dengan term al-Rijal dan al-Nisa'/al-Mar'ah (النساء، المرأ). Kata al-Rajul, jamaknya al-rijal, berasal dari akar kata $r$-j-l (رجل). Makna asal kata ini adalah anggota badan yakni kaki. Lalu kata ini menyimpang antara lain menjadi rajul yang bermakna laki-laki, lawan dari perempuan atau juga digunakan bagi perempuan yang menyerupai lakilaki (al-Ashfahânî, hal.194-195 dan ibn Fâris, hal. 444). Akar kata $r$-j-l dengan 
berbagai bentuknya terulang sebanyak 73 kali di dalam Al-Quran, dengan rincian; rajul sebanyak 24 kali; rajulani atau rajulain sebanyak 5 kali; rijal sebanyak 28 kali; semuanya untuk makna laki-laki dengan segala konteksnya. Selebihnya, 16 kali digunakan dalam bentuk rijl atau arjul yang bermakna kaki dengan segala konteksnya pula.

Khusus untuk kata rajul atau rijal, setidaknya ada beberapa maknanya konteksnya; rijal bermakna lelaki dalam kapasitas gendernya (QS.al-Baqarah/2: 282 dan 228, al-Nisa'/4: 34, 32, lalu; rajul atau rijal dalam pengertian 'orang'; lakilaki atau perempuan (misalnya QS.al-A`raf/6: 46 al-Ahzab/33: 23; rajul bermakna orang laki-laki nabi/rasul (misalnya QS.al-Anbiya'/21: 7, Saba'/34: 7); rajul dalam arti tokoh atau orang terkemuka di kaumnya (QS.Yasin/36: 20, al-A raf/7: 48); rajul dalam arti budak (QS.al-Zumar/39: 29). Juga rajul dalam pengertian berjenis kelamin laki-laki (misalnya QS.al-Nisa'/4: 1, al-Naml/27: 55) (( Abdul Bâqî, hal. 302-303 dan lihat juga Umar, hal.147-159). Dengan demikian, term rajul dan rijal tidak semata bermakna berjenis kelamin laki-laki secara biologis, tetapi juga lakilaki dalam pengertian gender. Jadi, kata ini bernuansa kelamin dan gender sekaligus.

Kata mar'ah berasal dari akar kata $m-r-a(\omega ر ء)$, artinya seseorang. Ketika digunakan dalam bentuk imra'ah dan mar'ah maka ia bermakna seseorang wanita (mu'anntas). Pembentukan kata ini merupakan proses yang tidak terpola (alAshfahânî, hal. 485 dan ibn Fâris, hal. 981). Secara keseluruhan dalam berbagai bentuk akar kata imra'ah dan mar'ah ini digunakan sebanyak 38 kali.

Dalam kaitan jenis kelamin manusia, akar kata imra'ah dan mar'ah ini digunakan dalam bentuk al-mar' $u$ bermakna seseorang secara umum, bisa laki-laki dan bisa perempuan (al-Baqarah/2: 102, al-Anfal/8: 24), 'Abasa/80: 34. Terkadang digunakan dalam bentuk imri' untuk makna al-mar'u (QS.al-Nur/24: 11, alThur/52: 21, dll.). Ketika digunakan dalam bentuk imra'ah ia hanya bermakna manusia perempuan atau istri. Imra'ah digunakan sebanyak 26 kali, dan tidak pernah digunakan dalam bentuk al-mar'ah. Kata imra'ah dalam makna umum antara lain pada QS.al-Nisa'/4: 12, 128, al-Naml/27: 23, al-Ahzab/33: 50, dan al- 
Baqarah/2: 282. Sedangkan pada banyak ayat kata imra'ah lebih disebut sebagai istri dari tokoh tertentu; imra'ah Imran (Alu Imran/3: 35), imra'ah al-'aziz (Yusuf/12: 30, 51), imra 'ah Fir'aun (al-Qashash/28: 9, al-Tahrim/66: 11), Imra'ah Nuh (al-Tahrim/66: 10), dan Imra'ah Luth (al-Tahrim/66: 10) ('Abdul Bâqî, hal. $663)$.

Al-Nisa' atau al-niswah dipandang sebagai bentuk jamak dari kata alimra'ah atau al-mar'ah. Kata al-Nisa' disepadankan atau lawan dari kata al-rajul atau al-rijal, sehingga ia tidak selalu digunakan untuk makna perempuan sebagai jenis kelamin, melainkan perempuan dalam kapasitas gendernya. Kata al-nisa' dalam berbagai bentuknya diulang di dalam Al-Quran sebanyak 59 kali, dengan rincian; niswah hanya 2 kali (QS.Yusuf/12: 30, 50), dan selebihnya dalam bentuk nisa ' atau al-nisa'. Dalam hal makna, kata al-nisa' digunakan setidaknya untuk tiga makna saja; Pertama, nisa' dalam arti kapasitas gender perempuan (misalnya pada al-Nisa'/4: 32 tentang hasil usaha yang diperoleh perempuan, tentang pembagian harta warisan QS.al-Nisa'/4: 7); Kedua, nisa' dalam arti istri atau peran domistik rumah tangga (misalnya QS.al-Baqarah/2: 222 tentang menjauhi istri waktu haidh, al-Baqarah/2: 223 tentang wanita harts bagi suaminya), dan Ketiga, nisa' sebagai berjenis kelamin perempuan (QS.al-Nisa’/4: 1) ('Abdul Bâqî, hal. 699, juga Umar, hal. 159-164).

Dengan demikian, penggunaan term al-rijal dan al-nisa' oleh Al-Quran selain merujuk kelamin biologis, juga merujuk pada kelamin social dalam arti gender. Dalam hal ini Al-Quran membedakan peran laki-laki dan peran perempuan, yang sesuai dengan kodratnya, antara lain dalam kaitan seksualitas, yakni peran sebagai suami dan peran sebagai istri, yang memang berbeda.

\section{Term Term Al-Quran tentang Kondisi/Fungsi Kelamin sebagai Alat Reproduksi}

Salah satu term Al-Quran tentang kondisi kelamin reproduksi manusia adalah term al-`Aqim (العقيم) (Mandul). Kata `aqim berasal dari akar kata `a-q-m. Kata `aqim berasal dari akar kata ` $a-q-m$, makna asalnya adalah sesuatu yang tidak mampu atau tidak bisa menerima pengaruh apapun. Kata ini digunakan kepada 
wanita berarti wanita yang tidak bisa menerima pembuahan alias mandul (alAshfahânî, hal.355). Kata al-`aqim hanya disebut di dalam Al-Quran sebanyak 4 kali (QS.al-Hajj/22: 55, al-Dzariyat/51: 29 dan 41, serta al-Syura/42: 50). Kata ini antara lain juga digunakan untuk menyebut hari kiamat (QS.al-Hajj/22: 55), pada QS. al-Dzariyat/51: 41 untuk menyebut sifat angin yang membinasakan. Selebihnya memang untuk makna mandul; pada al-Dzariyat/51: 29 (tentang istri Nabi Ibrahim yang mandul) dan al-Syura/42: 50 (tentang Allah memandulkan siapa yang dikehendakinya) ('Abdul Bâqî, hal. 469).

Dengan demikian, term `aqim menunjukkan dan merujuk suatu istilah dalam medis yakni mandul (tidak dapat memiliki anak) (Tim Penyusun Kamus Besar, 2002, hal. 710). Arti mandul bagi pria adalah tidak mampu menghasilkan kehamilan pada wanita karena buah pelir tidak dapat memproduksi sel spermatozoa sama sekali. Bagi wanita mandul adalah tidak mampu hamil karena indung telur mengalami kerusakan sehingga tidak mampu memproduksi sel telur. Kemandulan tidak dapat diatasi dengan apapun, karena kerusakan yang bersifat permanent pada buah pelir dan indung telur sehingga masing-masing tidak dapat berproduksi. Lain halnya dengan infertilitas (gangguan kesuburan). Pria infertile adalah yang memiliki sperma tetapi tidak dalam formula yang normal, dan wanita infertile ialah yang memiliki indung telur tetapi tidak dalam kualitas baik. Masalah kesuburan ada yang bisa diatasi dan ada yang tidak bisa diatasi, tergantung pada faktor penyebabnya (Pangkahila, 2001, hal. 151-157).

Term lain yang digunakan Al-Quran tentang kelamin reproduksi manusia adalah term al-Bikr (البكر): Virgin/Virginitas/perawan. Kata bikr berasal dari akar kata $b$-k-r (ب_ك-ر), yang di dalam Al-Quran digunakan dalam bentuk isim/kata

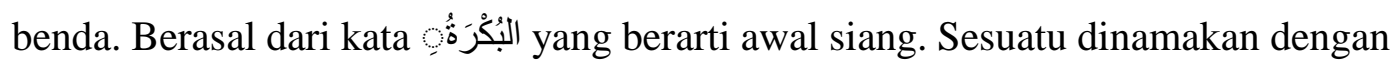
$b-k-r$ karena kondisinya pada posisi paling awal atau masih asli. Ketika digunakan dalam bentuk bikr yang dimaksud adalah seorang wanita yang belum pernah melahirkan artinya masih perawan (al-Ashfahânî, hal. 55).

Akar kata $b-k-r$ semuanya digunakan Al-Quran sebanyak 12 kali; digunakan untuk menunjuk waktu yaitu bukrah sebanyak 7 kali dan ibkar 2 kali, dan 
digunakan dalam kaitan seksual 3 kali yakni kata bikr hanya disebut 1 kali (QS.alBaqarah/2: 68) dan jamaknya abkar sebanyak 2 kali (QS.al-Waqi`ah/56: 36, alTahrim/66: 5). Kata abkar digunakan Al-Quran pada ayat-ayat ini dalam kaitan gadis bidadari perawan di surga (QS.al-Waqi'ah/56: 36) dan perawan di dunia (QS.al-Tahrim/66: 5). Kata bikr pada QS.al-Baqarah/2: 68 digunakan untuk menyebut sapi yang belum hamil atau melahirkan (Abdul Bâqî, hal. 133).

Dari telaah singkat di atas, dapat ditegaskan bahwa penggunaan term $b i k r$ atau abkar oleh Al-Quran sekedar menyebut kondisi dimana seekor binatang atau seorang wanita masih perawan atau belum melahirkan, bukan untuk menjelaskan apa itu firginitas. Perawan adalah anak perempuan yang sudah patut kawin atau anak dara atau gadis yang belum bersetubuh dengan pria alias masih murni (Tim Penyusun Kamus Besar, hal. 855.).

Keperawanan atau virginitas dalam diri seorang wanita adalah sebuah kehormatan dan harga diri yang harus dipertahankan hingga menikah dan berhubungan dengan suami. Sebab, bilamana ia sudah tidak perawan tanpa melalui pernikahan halal maka seorang wanita dianggap sudah ternoda dan terhina. AlQuran tidak menggunakan term 'perawan' ini untuk laki-laki. Hanya kepada perempuan. Hal itu sesuai dengan makna perawan 'bikr' itu, yakni kondisinya pada posisi paling awal atau masih asli, masih suci, alias belum dipakai oleh siapapun. Ini mengingat perempuan dalam relasi seksual menurut Al-Quran adalah wadah alharts alias sawah ladang bagi laki-laki. Nah, perawan adalah perempuan yang belum mengalami hubungan seksual baik halal maupun tidak halal, dari laki-laki manapun. Sedangkan laki-laki dalam posisi yang sama harus mempertahankan kesucian atau kehormatan mereka, sebaegaimana sudah dikemukakan pada kajian tentang al-farj, meskipun mereka tidak disebut dengan 'perawan'.

Selain soal kelaminnya, Al-Quran juga membicarakan hasrat seksual kelamin manusia untuk berproduksi. Term yang digunaan Al-Quran adalah alSyahwah (الثهوة) (Nafsu Syahwat). Kata syahwah berasal dari akar kata $s y-h-w$ (شهو), yang artinya hasrat terhadap sesuatu yang diinginkan (al-Ashfahânî, hal. 276-278). Kata ini antara lain diungkap dengan istilah حب الثهوات (menyukai 
syahwat) yang terdiri dari dua kata; حب (hubb) yang berarti keinginan terhadap yang dilihat atau memandang baik sesuatu (al-Ashfahânî, hal. 276-278).

Akar kata syahwah ini digunakan Al-Quran sebanyak 13 kali. 8 kali di antaranya digunakan dalam bentuk kata kerja isytahat-tasytahi, biasanya disandingkan dengan kata anfus (nafsu, jiwa). Sementara dalam bentuk syahwah (tunggal) digunakan sebanyak 2 kali (QS.al-A`raf/7: 81 dan al-Naml/27: 55) dan dalam bentuk syahawat sebanyak 3 kali (QS.Alu Imran/3: 14, al-Nisa'/4: 27 dan Maryam/19: 59) (Abdul Bâqî, hal. 390-391). Secara literal kata syahwah tidak semata bermakna nafsu seksual, tetapi nafsu secara umum (al-Ashfahânî, hal. 102103).

Terkait QS.Alu Imran/3: 14 misalnya, Shihab menjelaskan bahwa ayat ini menyatakan dijadikan indah bagi manusia kecintaan kepada aneka syahwat yakni aneka keinginan. Dijadikan indah bisa dalam arti ia benar-benar indah lalu dirasakan indah, atau ia buruk tetapi diperindah. Ayat ini menjelaskan hal yang diperindah yakni kecintaan kepada syahwat. Syahwat adalah kecenderungan hati yang sulit dibendung kepada sesuatu yang bersifat inderawi dan material. Hal yang dijadikan indah adalah kecintaan kepada hal-hal yang disebutkan, bukan syahwah itu sendiri. Ini menunjukkan bahwa syahwah kepada wanita dan sebagainya itu manakala sudah dicintai, akan sulit terbendung. Ayat ini mengandung kehalusan bahasa bahwa lelaki memiliki rasa cinta syahwat kepada wanita, bukan wanita objek syahwat bagi laki-laki (Shihab, Volume 2, hal. 25-26).

Selain itu, menurut penulis, digunakannya 'cinta dan syahwat' oleh lelaki kepada wanita, merupakan deskripsi realitas trend yang terjadi, karena lelaki memng lebih aktif, lebih ekpresif, dan menonjol dalam hal mencintai dan memulai gairah seksual kepada lawan jenisnya. Sedangkan perempuan dalam hal mengekspresikan cinta dan hasrat seksualnya kepada lelaki lebih pemalu, halus, dan tenang.

Adapun untuk menyebut orang yang tidak memiliki hasrat seksual lagi AlQuran menggunakan istilah atau term Ghair uli al-Irbah (غير أولى الإربة) (Tidak lagi Berhasrat Seks). Kata إربة berasal dari kata إرب yang berarti tidak memiliki 
keinginan. Sedangkan makna dari غير أولى الإربة adalah sindiran bagi laki-laki yang tidak punya hasrat terhadap wanita (al-Ashfahânî, hal. 11-12). Term Ghair uli alirbah (yang tidak memiliki keinginan), ungkapan ini hanya digunakan Al-Quran 1 kali yakni pada QS.an-Nuur/24: 31 (‘Abdul Bâqî, hal. 26).

Menurut Shihab adalah maksud ayat; atau pelayan-pelayan laki-laki yang tidak memiliki keinginan, yang dimaksud yakni berahi kepada wanita, seperti orang tua, atau anak-anak yang belum dewasa karena belum mengerti tentang aurat-aurat wanita sehingga belum memahami tentang seks atau hasrat seksual (Shihab, Volume 9, hal. 397). Dari penjelasan istilah pada ayat tentang Ghair uli al-Irbah tersebut menunjukkan bahwa faktor birahi seksual itu adalah hal yang factual, yang lazimnya muncul secara aktif dari pihak lelaki kepada perempuan, sehingga hal ini menjadi pertimbangan kenapa Islam mengatur cara dan adab berpakaian bagi pria dan wanita dalam kesehariannya.

Dengan demikian, penjelasan Al-Quran tentang fungsi dan kondisi kelamin manusia sebagai alat reproduksi bersifat umum, factual, simbolik, dan santun, serta berbasis kesetaraan. Al-Quran membicarakan masalah mandul dan subur, masalah perawan dan tidak perawan, cinta dan syahwat, serta pria tua dan anak-anak yang tidak lagi memiliki hasrat seksual, dan wanita yang sudah menopause. Semua ini menunjukkan humanistic dan etik Al-Quran dalam menjelaskan kondisi dan kualitas alat reproduksi manusia dalam menjalin hubungan suami istri.

\section{Term Al-Quran tentang Aktifitas dan Hubungan Seksual}

Term Ityan al-Harts (اتيان الحرث) (Mendatangi Ladang) dan Ityan al-Nisa' حرث Mendatangi Istri). Kata harts berasal dari kata $h$-r-ts (حرث). Kata) (اتيان النساء) arti aslinya menabur benih di lahan dan menyiapkannya untuk ditanami. Kata harts kemudian digunakan untuk menyebut hasil pertanian yakni kemakmuran, semisal kemakuran dunia dan akhirat (al-Ashfahânî, hal. 111).

Sementara kata ityan berasal dari akar kata $a-t-y$ (أتى), yang makna aslinya adalah datang atau mendatangi sesuatu dengan mudah. Kata ini kemudian digunakan untuk makna mendatangkan sesuatu, membayarkan sesuatu, 
melaksanakan sesuatu, dan atau membawa datang sesuatu (al-Ashfahânî, hal. 4). Semua bentuk derivasi akar kata $a-t-y$ (أنى) ini terulang di dalam Al-Quran sebanyak 550 kali.

Akar kata harts digunakan di dalam Al-Quran sebanyak 14 kali. Dari jumlah ini, hanya 1 kali digunakan dalam bentuk kata kerja; tahrutsun (QS.al-Waqi`ah/56: 63). Kata ini oleh Al-Quran, selain digunakan untuk makna membajak atau sawah ladang sebenarnya, juga digunakan untuk 'sawah ladang' metaforas/majaz, semisal istilah harts al-dunya dan harts al-akhirah (QS.al-Syura/42: 20), dan memetaforakan harts dalam kaitan seksualitas antara suami/laki-laki dan istri/perempuan (al-Baqarah/2: 223) (`Abdul Bâqî, al-Mu`jam al-Mufahras, hal. 4$11)$.

Pada QS.al-Baqarah/2: 222 dan 223 perempuan diibaratkan sebagai harts (lahan bagi laki-laki) dalam proses melanjutkan keturunan. Maka yang dimaksud di sini adalah menggauli istri. Kalimat فأتو هن من حيث امركم الله pada surat al-Thalaq dan al-Baqarah menunjukkan etika dalam melakukan hubungan suami istri. Mendatangi wanita hendaknya pada tempat yang seharusnya dan ketika mereka dalam keadaan suci (al-Ashfahânî, Mu'jam Mufrâdât, hal. 4). Shihab memahami dan menafsirkan bahwa ayat ini untuk menyatakan bahwa; 1) posisi istri dalam mewujudkan anak atau dalam relasi seksual hanya pihak penerima, suami pihak yang menanam, 2) suami harus menjaga dan mengembangkan 'sawah ladangnya' lahir batin agar bagus untuk bertanam demi pertumbuhan'anak'nya, dan 3) agar suami dalam melakukan hubungan seksual dengan istri agar melakukan penetrasi 'di lubang yang seharusnya/sewajarnya' untuk pembuahan, di luar itu adalah ketidaknormalan hubungan seksual (Shihab, Tafsir al-Mishbah, Volume 1, hal. 480-481). Dengan demikian, 'istilah mendatangi istri' adalah ungkapan yang halus dan sopan dalam mengungkapkan relasi seksual.

Term lain yang semakna digunakan Al-Quran adalah Ityan al-Nisa' ( تيان النساء) dalam arti wanita atau pasangan secara umum. Sebagaimana sudah disebutkan di atas, kata Ityan al-nisa' atau ityan al-zaujah digunakan untuk konteks aktifitas seksual secara umum, antara lain makna mendatangi istri (QS.al- 
Baqarah/2: 222, 223), atau mendatangi pasangan seksual yang menyimpang; lakilaki mendatangi sejenis (QS.al-A`raf/7: 80, 81, al-Syu’ara'/26: 165, al-Naml/27: 55, al-'Ankabut/29: 29,), serta digunakan pula untuk makna 'melakukan zina/perbuatan keji' (al-Nisa'/4: 15, 25, al-Nam1/27: 54, al-`Ankabut/29: 28, alAhzab/33: 30, al-Thalaq/65: 1) (Abdul Bâqî, al-Mu jam al-Mufahras, hal. 4-11).

Secara sederhana dapat dipahami bahwa istilah mendatangi istri atau pasangan seksual digunakan Al-Quran karena biasanya pihak laki-laki yang berperan aktif mendatangi istri/pasangannya untuk melakukan hubungan atau aktifitas seksual. Inilah bentuk kehalusan dan kehebatan bahasa Al-Quran dalam menyebut organ seks dan hubungan seksual; indah dan padat makna, serta memiliki nilai edukasi.

Term Mubasyarah al-Nisa’ (مباشرة النساء) dan Mu`asyarah al-Nisa’ ( معاثرة (النساء (Menggauli Istri). Term berasal dari akar kata b-sy-r (بشر). Basyar secara bahasa berarti kulit kepala, wajah, atau tubuh yang ditumbuhi rambut atau bulu (alAshfahânî, Mu'jam Mufrâdât, hal. 44-45).

Basyar menurut Quraish Shihab digunakan Al-Quran untuk menunjuk manusia dari sudut lahiriahnya serta persamaannya dengan manusia seluruhnya. Selain itu basyar juga menunjukkan bahwa manusia berkembangbiak melalui proses hubungan seks, karena kata basyiruhunna misalnya digunakan Al-Quran sebanyak dua kali (QS.al-Baqarah: 187) untuk makna melakukan hubungan seks dengan istri (Shihab, Wawasan Al-Qur'an, hal. 279). Kata ini ketika digunakan untuk mubasyarah istri maksudnya adalah menggauli istri/jima' (al-Ashfahânî, Mu'jam Mufrâdât, hal. 44-46. Lihat Shihab, Tafsir al-Mishbah, Volume 1, hal. 410411).

Penggunaan term mubasyarah ini mengondikasikan bahwa dalam melakukan hubungan dan atau aktifitas seksual, terjadi kontak kulit antara suami dan istri, karena keduanya tidak berpakaian, sehingga antara satu dan lainnya berfungsi sebagai pakaian bagi pasangannya. Akar kata basyar dengan semua turunannya digunakan Al-Quran sebanyak 123 kali. Akar kata basyar ini digunakan 
dalam bentuk mubasyarah terhadap istri/perempuan adalah sebanyak 2 kali yakni pada QS.al-Baqarah/2: 187 (Abdul Bâqî, al-Mu jam al-Mufahras, hal. 119-121).

Pada term mubasyarah terhadap istri masih menempatkan pria atau suami sebagai pihak yang aktif dalam melakukan hubungan seks, dan bahasa Al-Quran tentang hubungan seksual dengan term ini juga begitu halus; indah, tidak vulgar, dan penuh makna. Tetapi secara hakiki, posisi dan peran suami dan istri adalah setara, sesuai dengan pernyataan di awal ayat yang menyatakan; Nisa' Libas lakum dan Rijal Libas lahunna (هن لباس لكم و أنتم لباس لهن). Maksudnya bahwa suami dan istri merupakan pasangan yang setara; saling melengkapi, saling menutupi kekurangan, saling menjadi hiasan bagi pasangannya. Intinya, suami istri adalah pasangan saling membutuhkan (Shihab, Tafsir al-Mishbah, Volume 1, hal. 410411). Sebab, secara bahasa, kata libas berasal dari akar kata l-b-s (لبس), yang artinya menutupi sesuatu. Libas adalah sesuatu yang menutupi; pakaian disebut libas karena menutupi tubuh manusia (al-Ashfahânî, Mu’jam Mufrâdât, hal. 467). Pasangan suami istri disebut Al-Quran sebagai pasangan libas; saling melengkapi, saling menutupi kekurangan, saling menjadi hiasan bagi pasangannya, yang intinya saling membutuhkan.

Term lain yang digunakan Al-Quran adalah Mu asyarah al-Nisa’ ( معاثشرة النساء). Kata mu`asyarah terhadap wanita berasal dari akar kata `a-sy-r. Kata $m u^{`}$ asyarah berasal dari akar kata `a-sy-r. Kata ini makna adalah sesuatu yang sudah dikenal (ma`rufah) yakni angka 10. Kata `asyirah bermakna orang-orang yang sudah dikenal dan sangat dekat alias keluarga secara sempurna. Sebab angka 10 adalah angka sempurna. Maka mu`asyarah bermakna menggauli wanita seakan atau sebagai anggota keluarga dekat (al-Ashfahânî, Mu'jam Mufrâdât, hal. 347). Akar kata mu`asyarah ini dengan segala turunannya digunakan Al-Quran sebanyak 27 kali. Dalam arti mu`asyarah al-nisa digunakan hanya pada QS.al-Nisa'/4: 19 (Abdul Bâqî, al-Mu jam al-Mufahras, hal. 462).

Menurut Shihab, ada ulama yang memahami kalimat dan bergaullah dengan mereka secara makmruf, sebagai perintah buntuk berbuat baik kepada istri yang masih dicintai ataupun tidak. Makruf dalam arti tidak melukai, tidak memaksa, 
dan tidak mengganggu, bahkan lebih dari itu yakni dengan berbuat ihsan kepadanya. Sebab, hidup berkeluarga bertahan tidak mesti dengan cinta saja, ketika cinta sudah habis keluarga pun bubar, melainkan perlu dengan landasan makruf; berbuat baik dan yang terbaik. Tetapi secara umum para ulama memahami maksud ayat ini sebagai 'ucapan, perbuatan, tidur bersama, dan cinta, sesuai dengan ketentuan agama,' terhadap istri, dan tidak boleh dengan perilaku seksual menyimpang meskipun kepada pasangan sendiri dan halal (Shihab, Tafsir alMishbah, Volume 2, hal. 382-383). Itulah makna makruf tersebut.

Dengan demikian, meskipun dalam ungkapan mubasyarah dan mu`asyarah al-nisa' adalah hubungan dan pergaulan suami istri secara umum, yang normal, harmonis, dan setara, dan ini tidak secara eksplisit menunjuk hubungan seks, meskipun memang di dalamnya termasuk masalah hubungan seksualitas; hubungan seks antara suami dan istri.

Term al-Dukhul `Ala al-Nisa (الدخول على النساء) (Hubungan Seks). Kata $d u k h u l$ berasal dari akar kata $d$-kh-l. Kata دخول yang berarti masuk, lawan dari keluar. Kata dukhul ini digunakan untuk makna 'masuk' dari sisi waktu, tempat, maupun pekerjaan. Adapun term dukhul pada ungkapan دخول النساء bermakna 'tidur bersama dengan wanita/istri' sebagai ungkapan metafora untuk menyebut 'menggauli istri' (al-Ashfahânî, Mu'jam Mufrâdât, hal. 167).

Term dukhul ini dengan semua bentuknya digunakan Al-Quran secara keseluruhan sebanyak 125 kali. Term dukhul al-nisa' digunakan untuk makna menggauli istri adalah hanya pada QS.al-Nisa'/4: 23 (Abdul Bâqî, al-Mu jam alMufahras, hal. 253). Kalimat دخول النساءpada QS.al-Nisa'/4: 23 menurut Shihab, kalimat dakhaltum bihinna dengan makna mencampuri alias berhubungan seks, sebagai syarat haramnya anak tiri dinikahi bilamana seorang pria sudah menikah dan sudah berhubungan seks dengan ibu anak tiri tersebut (Shihab, Tafsir alMishbah, Volume 2, hal. 390-391). Ini merupakan istilah atau term yang agak jelas yang digunakan Al-Quran untuk menyebut huubungan seksual, yakni kalimat yang menunjukkan adanya hubungan seksual dengan kata yang menunjukkan adanya penetrasi organ seks pria kepada istrinya. Kejelasan ini dapat dimaklumi karena 
ayat ini sesungguhnya adalah menyangkut tentang halal dan tidaknya menikahi seseorang wanita, sehingga batasnya harus jelas yakni apakah wanita itu sudah mengalami adanya $d u k h u l$, atau tidak, bukan semata tidur bersama saja.

Term al-Rafats (الرفت) (Bercumbu dan Hubungan Seks). Kata رفث bahasa bermakna kata-kata yang mengandung kekejian manakala diungkapkan berkaitan dengan hal-hal sanggama dan pengantar kea rah sana. Maka rafats juga digunakan untuk makna jimak atau hubungan suami istri itu sendiri (al-Ashfahânî, Mu'jam Mufrâdât, hal. 205). Kata rafats digunakan Al-Quran hanya dua kali yakni pada QS.al-Baqarah/2: 187 dan 197 (Abdul Bâqî, al-Mu`jam al-Mufahras, hal. $333)$.

Shibab menafsirkan kata rafats pada ayat 187 dengan bercampur dengan istri, dan pada ayat 197 ditafsirkannya dengan bersetubuh dan atau bercumbu dengan istri (Shihab, Tafsir al-Mishbah, Volume 2, hal. 410 dan 433). Dengan demikian, kata rafats digunakan Al-Quran untuk menunjuk minimal adanya aktifitas seksual semisal bercumbu dan maksimal berupa hubungan seks alias bersetubuh dengan istri. Ini juga menunjukkan kehalusan bahasa Al-Quran, namun dengan menekankan bahwa ada unsur porno atau erotis atau kekejian ketika seseorang menyebut hubungan seks atau aktifitas seksual ketika diungkapkan ke orang lain.

Term Mulamasah al-Nisa (ملامسة النساء). Kata mulamasah al-nisa' berasal dari kata $l-m-s$ (لمس). Makna kata lams adalah ingin memperoleh wujud nyata sebuah kabar baik. Kata ini juga digunakan untuk makna meminta. Selain itu, dalam bentuk mulamasah kata ini digunakan secara metaforis untuk makna hubungan seks alias sanggama/jimak (al-Ashfahânî, Mu ’jam Mufrâdât, hal. 475). Kata l-m-s secara keseluruhan digunakan Al-Quran sebanyak 5 kali. Dalam bentuk mulamasah alnisa' hanya digunakan pada QS.al-Nisa'/4: 43 dan al-Maidah/5: 6 (Abdul Bâqî, alMu`jam al-Mufahras, hal. 653).

Ketika menjelaskan QS.al-Maidah/5: 6 Shihab menyebut lamastum al-nisa' sebagai ungkapan yang digunakan untuk mengekspresikan hal-hal yang seharusnya. Sementara ketika ia menjelaskan lamastum al-nisa' pada QS.al- 
Nisa'/4: 43 yang terjemahannya adalah kamu menyentuh perempuan, dipahami oleh Imam al-Syafi' I dalam arti persentuhan kulit dari jenis kelamin berbeda dan bukan mahram, baik dengan syahwat atau tidak. Imam Malik mensyaratkannya dengan syahwat, sedangkan Imam Abu Hanifah memahaminya dengan hubungan seks, sehingga dengan persentuhan kulit walau dengan syahwat tidak membatalkan wudhu'(Shihab, Tafsir al-Mishbah, Volume 3, hal. 37 dan Volume 2, hal. 453). Dengan demikian, ungkapan lamastum al-nisa' setidaknya secara bahasa dan tafsir bisa dipahami sebagai hubungan seks atau minimal aktifitas seksual antarsuamiisteri semisal menyentuh, meraba, bercumbu, dan sebagainya.

Term Mass al-Nisa' (مس النساء) (Menikahi/Menggauli Perempuan). Akar kata mass berasal dari akar kata $m-s-s$ (مس). Kata ini secara literal mirip dengan kata lams, hanya dalam lams terdapat keharusan mencari atau meminta sesuatu meskipun tidak diperoleh sama sekali. Dalam kata mass terdapat makna keinginan menyentuh sesuatu secara inderawi. Maka kata mass kemudian secara metaforis digunakan untuk menyebut nikah, orang gila, atau sesuatu hal buruk yang menimpa manusia (al-Ashfahânî, Mu ’jam Mufrâdât, hal. 487). Kata mass ini digunakan AlQuran sebanyak 61 kali. Penggunaan kata ini untuk makna konteks hubungan seksual antara laki-laki dan perempuan adalah terdapat pada QS.al-Baqarah/2: 236, 237, al-Ahzab/33: 49, Alu Imran/3: 47, Maryam/19: 20, al-Mujadalah/58: 3-4 (Abdul Bâqî, al-Mu`jam al-Mufahras, hal. 666-667).

Shihab ketika menafsirkan QS.al-Baqarah/2: 236, 237 memaknai ungkapan selama kamu belum menyentuh mereka dalam arti belum melakukan hubungan seks dengan mereka. Jadi wanita yang diceraikan tidak ada kewajiban membayar mahar selama belum disetubuhi. Sebab, di sini tidak relevan dimaknai dengan dikawini karena pembicaraan ayat ini adalah masalah cerai yang terjadi pada orang yang sudah menikah (Shihab, Tafsir al-Mishbah, Volume 1, hal. 512). Tetapi ketika menafsirkan Alu Imran/3: 47, ia menafsirkannya dengan disentuh atau dinikahi. Artinya, Maryam jangankan berhubungan seks yang menyebabkan kehamilan, menikah saja belum (Shihab, Tafsir al-Mishbah, Volume 2, hal. 94). Namun pada 
QS.Maryam/19: 20 kata ini ditafsirkannya dengan makna berhubungan seks yang halal (Shihab, Tafsir al-Mishbah, Volume 8, hal. 167).

Dengan demikian, dapat disimpulkan bahwa mass al-nisa' mengandung makna menikah secara umum, tetapi ia bisa dimaknai melakukan hubungan seks atau aktifitas seksual semisal meraba atau menyentuh wanita.

Term al-Rawd (الرود) dan Hamm (الهم) (Menggoda dan Berhasrat). Kata rawd berasal dari akar kata $r-w-d(ر و د)$. Kata ini bermakna berulang-ulang meminta sesuatu dengan halus dan lembut. Dari kata ini lahir kata iradah yaitu seuatu keinginan dan kekuatan yang terbentuk dari adanya syahwat, kebutuhan, dan citacita. Maka, kemudian kata murawadah bermakna menantang atau menginginkan orang lain agar mengikuti keinginan anda, sehingga anda menghendaki apa yang tidak dia inginkan atau sukai, semisal apa yang terjadi pada kisah Yusuf as (alAshfahânî, Mu’jam Mufrâdât, hal. 211-212).

Kata rawada atau rawadat ini digunakan Al-Quran hanya pada QS.Yusuf/12: 23,26, 32,51 dalam kisah Nabi Yusuf (Abdul Bâqî, al-Mu jam alMufahras, hal. 328). Makna راود pada surat Yusuf ini adalah godaan/rayuan untuk melakukan kemaksiatan. Atau dalam ungkapan lain; menggoda, merayu, dan memaksa Yusuf untuk melakukan hubungan atau aktifitas seksual dengannya. Adanya upaya demikian adalah karena adanya hasrat nafsu seksual kepada lawan jenis dalam diri wanita tersebut dan dalam diri Yusuf (QS.Yusuf/12: 24) (Shihab, Tafsir al-Mishbah, Volume 6, hal. 428-429). Hal ini adalah sebuah kenormalan. Tetapi upaya menggoda dengan paksa sudah tidak wajar dan normal. Sang wanita mewujudkannya dengan menggoda kuat terhadap Yusuf agar mau melakukan hal yang diinginkannya.

Term hamm bermakna bermakna kesedihan yang membuat manusia terbebani, kemudian digunakan untuk makna keinginan yang membebani (alAshfahânî, Mu'jam Mufrâdât, hal. 543 dan Ibn Zakariya, al-Maqayis, hal.1056). Terkait makna hamm pada kisah Nabi Yusuf dan Imr'at al-Aziz, menurut Shihab, bahwa wanita itu telah bermaksud dengan penuh tekad melakukan kedurhakaan dengannya, karena tidak ada akal dan moral atau agama yang membendungnya, 
hasratnyapun meluap-luap, dan diapun yakni Yusuf anak muda yang tampan lagi sehat bugar telah bermaksud juga melakukan sesuatu dengannya andaikan dia tidak melihat bukti dari Tuhannya (Shihab, Tafsir al-Mishbah, Volume 6, hal. 428-432). Dengan demikian, term hamma juga mengindikasikan nuansa makna hasrat seksual di dalamnya.

Demikianlah beberapa term dan atau ungkapan Al-Quran tentang aktifitas dan hubungan seksual, yang dari sisi pendidikan, menunjukkan keberagaman dan kehalusan bahasa Al-Quran di satu sisi sesuai relevansinya, dan keterusterangan ayat di sisi lain sesuai relevansinya. Selain itu, deskripsi Al-Quran tentang aktifitas dan hubungan seksualitas antara suami dan istri, juga menunjukkan sifat yang realistic, dimana posisi lelaki lebih menonjol daripada perempuan. Namun secara gender, Al-Quran mengisyaratkan bahwa hubungan seksual antara suami dan isteri harus berbasis cinta, hasrat biologis yang kuat, dan cara yang halal dan normal, tidak boleh ddalam hubungan haram dan menyimpang. Posisi lelaki/suami dan perempuan/isteri pada hakikatnya adalah sama alias mitra, namun dari sisi peran lelaki yang lebih aktif dan utama.

\section{KAJIAN/DISKUSI}

Dari kajian bagian awal, dapat dinyatakan bahwa Al-Quran ketika menggunakan term dan atau mendeskripsikan tentang seks dan seksualitas manusia memang terjauh dari unsur porno dan vulgaritas, dan focus pada penyampaian hokum dan norma. Misalnya, term-term Al-Quran yang bernuansa penjelasan tentang kelamin secara bilogis manusia bersifat variatif dengan menggunakan beberapa istilah dengan penekanan makna konotasi berbeda. Faraj lebih pada organ atau wilayah kelamin yang berongga atau tersembunyi, sehingga memalukan jika terbuka; sau'ah lebih menekankan kelamin sebagai suatu yang harus ditutup karena akan mengakibatkan malu atau kekejian, dan dzakar atau untsa yang lebih menekankan karakter manusia yang berkelamin laki-laki dan perempuan yakni maskulin dan feminine, kuat dan lembut. Meskipun demikian, tidak ada term yang secara vulgar mendeskripsikan bentuk fisik organ seksual, karena memang tidak penting. 
Demikian juga ketika menjelaskan aktifitas dan hubungan seksual, umumnya bersifat bahasa yang halus dan sopan, kecuali term dukhul al-nisa' yang terkesan lebih eksplisit tentang hubungan seks. Tetapi hal ini dapat dimaklumi karena pembicaraan ayat yang menggunakan term ini terkait dengan ketentuan boleh menikah dengan kriteria apakah seseorang belum atau sudah melakukan hubungan seks dengan istrinya atau belum.

Penjelasan Al-Quran tentang seks dan seksualitas sesungguhnya bersifat lengkap karena terkait pelbagai aspek, integral dan komprehensif karena antara satu sama lain memiliki kaitan dan relevansi. Sebab, aspek-aspek seksualitas manusia yang diungkap atau dijelaskan Al-Quran juga sangat luas; tentang hal ihwal alamiah kelamin seks, tentang hasrat dan potensi seksual seseorang, tentang pmekanisme pemenuhan hasrat seksual berupa aktifitas dan hubungan seksual, tentang perilaku seksual yang terpuji dan tercela, dan sebagainya. Meskipun belum semua term AlQuran yang bernuansa seksualitas yang dikaji, namun apa yang sudah diteliti menunjukkan kompleksitas, interalitas, dan komprehensifitas bimbingan Al-Quran tentang seks dan seksualitas.

Deskripsi Al-Quran tentang seksualitas manusia senantiasa menyatu dengan pembahasan masalah hukum dan akhlak, iman dan ibadah. Artinya, pembicaraan term dan atau deskripsi Al-Quran tentang seks dan seksualitas manusia tidak focus ke masalah seks itu sendiri, melainkan terkait dengan hal-hal prinsip semisal hukum, sunnatullah, akhlak, dan sebagainya. Artinya, pembicaraan Al-Quran tentang seksualitas manusia tidak semata masalah seks, melainkan masalag manusiawi dan teks suci yang mengandung ajaran ilahi di dalamnya guna mengedukasi manusia.

Dikaitkan dengan pendidikan seksualitas bagi generasi muda Islam, yaitu upaya memperkenalkan dan memahamkan masalah seks dan seksualitas secara jelas dan benar, maka model deskripsi Al-Quran ini bisa dijadikan acuan. Hal ini selain untuk mengurangsi ketabuan dan kerancuan, pendidikan seksualitas Qurani ini akan mengeleminir unsure cabul dan porno di dalamnya sekaligus menumbuhkan nuansa ilmiah dan ubudiyah. 


\section{PENUTUP}

1. Dari hasil penelitian ini dapat disimpulkan bahwa deskripsi Al-Quran yang bernuansa seks dan seksualitas menyatu dengan pembahasan masalah hukum dan akhlak, iman dan ibadah. Artinya, pembicaraan term dan atau deskripsi AlQuran tentang seks dan seksualitas manusia tidak focus ke masalah seks itu sendiri, melainkan terkait dengan hal-hal prinsip semisal hukum, sunnatullah, akhlak, dan sebagainya. Maka Al-Quran ketika menggunakan term dan atau mendeskripsikan tentang seks dan seksualitas manusia tidak porno, tidak vulgar, melainkan penuh denga kehalusan, simbolik, dan edukatif.

2. Secara khusus dapat dikemukakan bahwa Al-Quran mengungkap organ dan jenis kelamin biologis manusia secara objektif dan realistik, dengan pelbagai dimensinya. Term farj, sau'ah, dzakar dan untsa, digunakan Al-Quran tidak menonjolkan vulgaritas atau porno, juga tidak secara tegas untuk membedakan gender mereka, melainkan pada eksistensi dan sifat alamiah, serta pentingnya penjagaan dan pemeliharaan kelamin dari perbuatan tercela dan keji.

a. Al-Quran mendeskripsikan kelamin manusia sebagai identitas gender; dengan term al-rijal dan al-nisa', al-mar'ah selain merujuk kelamin biologis, juga merujuk pada kelamin social dalam arti gender. Dalam hal ini Al-Quran membedakan peran laki-laki dan peran perempuan, yang sesuai dengan kodratnya, antara lain dalam kaitan seksualitas, yakni peran sebagai suami dan peran sebagai istri, yang memang berbeda.

b. Al-Quran mendeskripsikan tentang kondisi/fungsi kelamin manusia sebagai alat reproduksi; Dengan demikian, penjelasan Al-Quran tentang fungsi dan kondisi kelamin manusia sebagai alat reproduksi bersifat umum, factual, simbolik, dan santun, serta berbasis kesetaraan. Al-Quran membicarakan masalah mandul dan subur, masalah perawan dan tidak perawan, cinta dan syahwat, serta pria tua dan anak-anak yang tidak lagi memiliki hasrat seksual, dan wanita yang sudah menopause. Semua ini menunjukkan humanistic dan etik Al-Quran dalam menjelaskan kondisi dan kualitas alat reproduksi manusia dalam menjalin hubungan suami istri. 
c. Al-Quran mendeskripsikan tentang aktifitas dan hubungan seksual; beberapa term dan atau ungkapan Al-Quran tentang aktifitas dan hubungan seksual, dari sisi pendidikan, menunjukkan keberagaman dan kehalusan bahasa di satu sisi dan keterusterangan di sisi lain. Secara gender, Al-Quran mengisyaratkan bahwa hubungan seksual antara suami dan isteri harus berbasis cinta, hasrat biologis yang kuat, dan cara yang halal dan normal, tidak boleh dalam hubungan haram dan menyimpang. Posisi lelaki/suami dan perempuan/isteri pada hakikatnya adalah sama alias mitra, namun dari sisi peran lelaki yang lebih aktif dan utama.

Sehubungan dengan hasil di atas, maka penulis merekomendasikan;

a) Diperlukan pendidikan seks dan seksualitas yang objektif dan penuh tanggungjawab kepada semua orang,

b) Dalam menginformasikan dan atau mengajarkan seks dan seksualitas, perlu digunakan penyesuain pilihan bahasa atau kata, ketika pendidikan (ilmu pengetahuan dan bimbingan) tentang seks dan seksualitas diberikan untuk tujuan berbeda dan atau untuk orang yang berbeda pula,

c) Dalam memberikan pendidikan (ilmu pengetahuan dan bimbingan) tentang seks dan seksualitas, diperlukan bahasa yang baik, sopan, namun akurat dalam menjelaskan masalah seks dan seksualitas,

d) Kelengkapan term dan deskripsi Al-Quran dalam menggunakan term dan atau mendeskripsikan tentang seks dan seksualitas manusia dapat dijadikan acuan dalam mengatasi masalah sosial yang terkait dengan perilaku seksual dan atau penyimpangan seksual dengan segala dampak negatifnya.

Berdasarkan kesimpulan di atas, maka penulis juga menyarankan perlunya penelitian lanjutan yang lebih lengkap, dan lebih detail, agar apa yang diinginkan Al-Quran ketika membicarakan masalah seks dan seksualitas dapat dipahami dan dipergunakan dengan baik dan benar. 


\section{DAFTAR PUSTAKA}

Abdul Bâqî, Muhammad Fu'ad, al-Mưjam al-Mufahras li Alfâzh al-Qur'ân alKarîm, Beirût: Dâr al-Fikr, 1987, Tanpa Cet.ke.

Adams, Lewis Mulford (Managing Editor), Webster's World University Dictionary, Washington DC: Publisher Company.Inc., 1965

Ali, Attabik, dkk., Kamus Kontemporer Arab-Indonesia, Krapyak: Pesantren Krapyak, 1996

Anîs, Ibrâhîm,, dkk., al-Mu'jam al-Wasîth, Beirût: Dâr al-Ma`ârif, 1972, Cet. II

Ashfahânî, Al-Râghib, Mufradât Gharib al-Qur'ân al-Karîm, Beirut: Dâr alMa`arif, tp.th..

Asmu i MS, Oral Sex dalam Pandangan Islam dan Medis, Jakarta: Abla Publihser, 2004, Cet. I

Bucaille, Maurice, Bibel, Quran, dan Sains Modern, Jakarta: Bulan Bintang, 2007, Cet.16, Penerjemah; HM.Rasyidi

Chaplin, James P, Kamus Lengkap Psikologi, Jakarta: Rajawalui,1989, Edisi I, Cet.1

Djubaidah, Neng, Pornografi dan Pornoaksi Ditinjau dari Hukum Islam, (Jakarta: Prenada Media, 2004) Cet. III

Durkheim, Emile, Pendidikan Moral; Suatu Studi Teori dan Aplikasi Sosiologi Pendidikan, Jakarta: Erlangga, 1990, Penerjemah: Lukas Ginting, judul asli (Inggris), Moral Education, Cet.I

Farmawî, `Abd al-Hayy, Metode Tafsir Maudhu iy: Sebuah Pengantar, Jakarta: Rajawali Pers dan LSIK, 1994, penerjemah: Suryan A.Jamrah, judul asli;

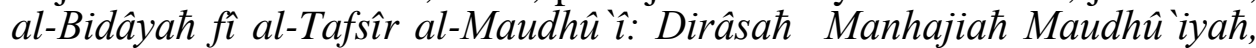
Kairo: Matba`aћ Nahdhah al-`Arabiyaћ, Cet.I

Gunawan, FX.Rudy dan Seno Joko Suyono, Wild Reality: Refleksi Kelamin dan Sejarah Pornografi, Jakarta: Gagas Media, 2003, Cet.I

Hidayat, Komaruddin, Menafsirkan Kehendak Tuhan, Jakarta: Teraju, 2004, Cet. II

Hutapea, Ronald, Aids dan PMS dan Perkosaan, Jakarta: Rineka Cipta, 1995, Cet. $\mathrm{I}$,

Ibn Katsîr, Abu al-Fidâ', Tafsîr al-Qur'ân al-`Azhîm, Beirût: Dâr al-Fikr, 1992, Edisi Baru, Cet.I, Jilid III

Ibn Manzhur, Lisan al-`Arab, Beirut: Dar Ihya al-Turats al-`Arabi, 1988

, Lisan al-Arab al-Muhith, Beirut: Dar Lisan al-Arab, tth

Izutsu, Thosihiko, Konsep Etika Religius dalam Al-Quran, Yogyakarta: Tiara Wacana, 1993, judul asli; Ethico Religius Consepts In The Qur'an

Jaiz, Hartono Ahmad, Al-Quran Dihina Gus Dur, Jakarta: Hujjah Press, 2006, buku dalam versi ebook dalam Swara Muslim Cyber Book).

Krippendorff, Klaus, Analisis Isi: Pengantar Teori dan Metodologi, Jakarta: RajaGrafindo, 1993, Cet. 1

Lesmana, Tjipta, Pornografi dalam Media Massa, Jakarta: Puspa Swara, 1995, Cet.I, 
Ma`luf, Luis, al-Munjid fi al-Lughah wa al-A`lam, Beirut: Dar al-Masyriq, 1986

Manuaba, Ida Bagus Gde, Memahami Kesehatan Reproduksi Wanita, Jakarta: Arcan, 1999

Munawwir, Ahmad Warson, Kamus al-Munawwir, Surabaya: Pustaka Progressif,1997

Muslim, Mushthafâ, Mabâhits fì al-Tafsîr al-Maudhû'î, Damaskus: Dâr al-Qalam, 1989, Cet. I

Nahlawi, `Abd al-Rahman, Prinsip-prinsip dan Metode Pendidikan Islam, Bandung: Diponegoro, 1989, Penerjemah: Herry Noer Ali, judul asli; Ushûl al-Tarbiyah al-Islâmiyah wa Asâlibuh, Cet.1

Nasution, Harun, Perlunya Menghidupkan Kembali Pendidikan Moral, dalam Saiful Mujani dan Arief Subhan (Editor), Pendidikan Agama dalam Perspektif Agama-agama, Jakarta: Logos Publishing House, 1995, Cet.I

Pangkahila, Wimpie, Seks yang Indah, Jakarta: Kompas, 2001, Cet.I

Poerwadarmita, W.J.S., Kamus Umum Bahasa Indonesia, Jakarta: Balai Psutaka, 1984, Cet.VII

Qâdhî, Ahmad 'Arafat, al-Fikr al-Tarbawî `inda al-Mutakallimîn al-Muslimîn, Mesir: al-Hai'ah al-Mishriyah al-'Ammah li al-Kutub, 1996, tanpa Cet. Ke.

Qaththan, Mana` Khalil, Mabahits fi Ulum al-Hadis, Riyadh: Mansyurat al-Ashr al-Hadis, 1973

Rahardjo, Muhammad Dawam, Ensiklopedi Al-Qur'an: Tafsir Sosial Berdasarkan Konsep-konsep Kunci, Jakarta: Paramadina, 2002, Cet.II

Sahil, Azharuddin, Indeks al-Quran: Panduan Mencari ayat al-Quran Berdasarkan Kata Dasarnya, Bandung:Mizan,1996, Cet.V

Sensa, Muhammad S Djarot S, Seks Dalam Islam, Bandung Sinar Baru,1993

Shihab, Muhammad Quraish Wawasan Al-Qur`an, Bandung: Mizan. 19976, Cet.V , Membumikan Al-Quran: Fungsi dan Peran Wahyu dalam Kehidupan Masyarakat, Bandung: Mizan, 1998, Cet. XVII

-------, Tafsir al-Mishbah; Pesan, Kesan, dan Keserasian Al-Qur'an, Jakarta: Lentera Hati, 2006, Cet. V

Suprayogo, Imam dan Tabroni dalam Metodologi Penelitian Sosial-Agama, Jakarta : Remaja Rosdakarya, 2001

Tim Penyusun Kamus Pusat Bahasa, Kamus Besar Bahasa Indonesia, Jakarta: Balai Pustaka, 2002, Edisi III, Cet. 2

Umar, Nasaruddin, Argumen Kesetaraan Gender Perspektif Al-Quran, Jakarta: Paramadina, 2001, Cet.II

Websters, Noah, Webster's New Twentieth Century Dictionary, USA: Wiliam's Collin's Publishers, 1980, Cet. II, Hasil revisi Jean L. Mc. Kechivic

Wehr, Hans, A Dictionary of Modern Written Arabic, Beirut: Libraire du Liban/London: Macdonald \& Evans Ltd. 1980, Cet.III

Zuhailliy, Wahbah Musthafa, Al-Qur'an al-Karim : Bunyatuh al-Tasyri'iyah wa Khasha'ishuh al-Hadhariyah. Damaskus: Dar al-Fikr, 1993, Cet.I. 